\title{
A CONSTRUÇÃO DO EU NA MODERNIDADE: DO PROJETO ROMÂNTICO AO IMPRESSIONISMO EM FREUD
}

Denise Coutinho

Psicóloga, psicanalista, tradutora. Doutora em Letras pela Universidade Federal da Bahia, com doutoradosanduíche em Princeton University. Professora-adjunta da Universidade Federal da Bahia.

RESUMO: O sistema cartesiano fornece as bases para o Romantismo produzir um novo objeto: o 'eu' simultaneamente interioridade e alteridade. Tal invenção incide sobre os campos científico, político, social, artístico e produz consequências éticas e estéticas que perduram no século XXI. Pretende-se, aqui, propor uma aproximação do estilo de Freud com o impressionismo, sem deixar de reconhecer, no pensamento literário romântico, o ponto de inflexão na produção de uma nova racionalidade. Apontar a emergência do eu, tal como (re)apresentado por Freud, implica reconhecê-lo como tributário do ideal romântico. Ao mesmo tempo, tenta-se destacar a virada epistemológica que Freud imprime ao conceito numa proposta ainda hoje subversiva.

Palavras-chave: Romantismo; invenção do eu; psicanálise; impressionismo.

ABSTRACT: The construction of the Self in Modernity: Romanticism and Impressionism in Freud. The Cartesian system provides the fundamental principles for Romanticism to produce a new object: the 'self', simultaneously as interiority and alterity. This invention falls on the scientific, political, social, and artistic fields that produce ethical and aesthetic consequences that endured in the 21 st century. The aim of this essay is to offer an approximation between Freud's style and Impressionism, while recognizing the point of inflection in the production of a new rationality in the literary romantic thought. Pointing to the emergence of the self, as (re)presented by Freud means to recognize it as a tributary of the romantic ideal. At the same time, it highlights the epistemological change that Freud imprints on this concept in a proposal that has remained subversive until today.

Keywords: Romanticism, invention of "self”, psychoanalysis, Impressionism. 
$\mathrm{U}_{\mathrm{n}}^{\mathrm{n}}$ m dos quadros mais eloquentes do pintor Claude Vernet (1714-1789) é O naufrágio. Trata-se, de fato, de um tema recorrente na obra de grandes pintores românticos, Friedrich, Turner, Martin, Delacroix: ondas espumantes em fúria emolduram, ameaçadoras, um bando de náufragos sobreviventes. A aventura da modernidade conduzira à experiência de um mundo em ruínas. Tormentas da antiga natureza agora ornamentam tempestades da alma. Mas, como em qualquer movimento ou estilo de época, também o romantismo produziu uma fresta justamente no ponto que pretendia obturar. Tomar uma possível gênese do romantismo no projeto racional do Renascimento e considerá-lo como gérmen da virada impressionista implica destacar a produção do individualismo na constituição da subjetividade contemporânea.

Richard Rorty (1993), talvez o mais importante filósofo estadunidense do século XX, considera a Revolução Francesa como marco de uma vertiginosa mudança no vocabulário das relações sociais e, consequentemente, de uma mudança igualmente rápida e transformadora de suas instituições. Deste modo, o século XVII teria sido o palco em que uma importante substituição é encenada: o amor a Deus cede lugar ao amor à verdade científica. Já no final do século XVIII, nova virada: o amor à verdade é substituído pelo amor-próprio, inaugurando o romantismo. Assim, passamos da natureza à paisagem, inquieta, desmedida, em que o fato (destino) já não tem lugar de existência, pois o projeto cartesiano frutificou: as luzes que focam a produção do si-mesmo fazem com que sentimentos, imaginação e inspiração libertam-se das amarras do corpo. Um novo objeto vinha sendo materializado desde as meditações cartesianas: o eu.

Rorty também invoca o período romântico europeu como uma época de ruptura da arte imitativa, no sentido platônico do termo, reivindicando um lugar para o artista até então inexistente na sociedade. A ideia que Rorty desenvolve é de que o romantismo traz consigo uma nova proposição para esta infindável rede de conversações que é o mundo humano. Um projeto que se configura ao mesmo tempo estético e ético. Segundo Rorty, o movimento romântico constitui um marco na renovação considerável de nosso vocabulário, sendo a descrição de si um dos pontos culminantes desta transformação linguística. Inventar um 'eu’ como alteridade confirma a experiência ficcional: as verdades são forjadas e não descobertas ou encontradas (RORTY, 1993).

Este artigo tem como objetivo traçar, na evolução do pensamento literário romântico do século XVIII, a produção de uma nova racionalidade. Enseja, ainda, apontar as implicações do romantismo no desenvolvimento do conceito de Eu, um dos pilares teóricos da psicanálise, tal como concebida por Sigmund Freud. Avançamos, então, uma hipótese: apesar de ter amplamente utilizado o conceito de Eu, o pensamento de Freud revela-se mais impressionista que romântico. Somente dessa maneira, conforme demonstraremos a seguir, podemos com- 
preender a recusa freudiana aos dualismos, o que sustenta a aposta psicanalítica nas descrições e redescrições possíveis (usando o vocabulário rortyano) de cada sujeito humano. Embora não seja o foco deste estudo, devemos salientar que esta é uma crítica frequentemente formulada à obra freudiana, o pretenso dualismo freudiano. É notório que Freud trabalha com dicotomias: pulsões de vida/pulsões de morte; princípio de prazer/princípio de realidade, mas não se pode confundir dicotomia com dualismo.

\section{O ROMANTISMO E A INVENÇÃO DO EU}

A produção poética ocidental está marcada, segundo Friedrich (1978), por duas obras do século XVIII, anunciando questões que não mais deixarão de ser retomadas. Os autores são Denis Diderot e Jean-Jacques Rousseau. Em comum, eles também possuem uma história de amizade e influências mútuas. Quando o jovem Diderot é preso por escrever uma irônica "Carta sobre os cegos para uso daqueles que veem”, seu amigo Rousseau vai visitá-lo na prisão. No trajeto, acidentalmente, lê o anúncio de um prêmio a ser concedido a quem respondesse se a restauração das artes e das ciências purificava a moral. Rousseau escreve o ensaio Discurso sobre as ciências e as artes e ganha o prêmio, tornando-se um escritor célebre. Sua tese acusa a civilização de corromper o homem através das ciências e das artes, e prega a volta à natureza. Uma indiferenciação proposital entre fantasia e realidade marca em Rousseau uma ruptura com a tradição literária. A obra rouseauniana sustenta o caráter radical da incomunicabilidade, prenunciando o modo romântico de existir. A militância por uma grande reforma social, seu engajamento com a música e numerosas doenças afastam Rousseau pouco a pouco dos amigos, inclusive Diderot.

Com uma obra cujo foco seria a ideia e não os conteúdos, Diderot promove a "decisiva preeminência da magia linguística sobre o conteúdo linguístico" (FRIEDRICH, 1978, p.27). Filósofo enciclopedista, faz da literatura um ofício com características muito peculiares. Uma de suas invenções é a introdução de uma discussão metaliterária com o leitor e suas expectativas, em Jacques, o fatalista. Ali, vemos Diderot desconstruir com maestria a narrativa linear e estabelecer descontinuidades, ironias e um debate entre narrador e leitor sobre os temas fatalismo e liberdade. Eis um dos trechos destacados por Todorov para exemplificar o papel do verossímil na arte: “Vão pensar [...] que vai haver uma coisa sangrenta, pancadaria e tiros, e só de mim dependeria que isso acontecesse; mas, nesse caso, adeus verdade da história, adeus narrativa dos amores de Jacques" (apud TODOROV, 2003, p.117). Diderot assume claramente um compromisso com a apresentação do verossímil e não mais com o leitor e a realidade; trata-se, portanto, como aponta Todorov (Idem, p.113 e passim), da submissão do autor às exigências próprias ao discurso. Têm início, pois, experiências artísticas cujo 
foco é a visão esteticamente positiva da desordem, da perplexidade, temas que Baudelaire irá mais tarde potencializar.

Considera-se Charles Baudelaire um dos inventores da palavra 'modernidade'. O primeiro registro do termo data de 1859. Entretanto, Rousseau antecipara o adjetivo 'modernista', cem anos antes. Ainda que separados por um século, ambos são contemporâneos na maneira de apreender a estrutura própria à escritura poética. O que se extrai do texto de Rousseau pode ser facilmente aplicado ao sentido da poética em Baudelaire: em ambos, o bom, o mau, o belo, o feio, a verdade, a virtude têm uma existência local e limitada. A poética de Baudelaire aproxima arte e ciência: "Beleza é o produto de razão e cálculo”, sendo que seu modo de conceituar o belo é paradoxal: "O belo é sempre bizarro" (BAUDELAIRE, 1855, em itálico no original).

Em Baudelaire, a metáfora adquire o valor de "exatidão matemática”; para tanto, ele se apoia em Edgard Alan Poe, que apontara o parentesco entre a ciência e as tarefas poéticas, aproximando-as do rigor lógico de um problema matemático. O lixo, o homem decadente, o artificial guiam a literatura por novos temas. Baudelaire reivindica uma atitude na qual ele próprio se vangloria por ativamente irritar o leitor: "A consciência poética, outrora uma fonte infinita de alegrias, tornou-se agora arsenal inesgotável de instrumentos de tortura” (apud FRIEDRICH, 1978, p.45).

Na mesma época, e com a prosa, Gustave Flaubert participa deste ato de ruptura. "Flaubert: uma maneira de cortar, de romper o discurso sem o tornar insensato. [...] pela primeira vez com Flaubert, a ruptura não é mais excepcional, esporádica, brilhante, engastada na matéria vil de um enunciado corrente [...] toda a moedinha lógica está nos interstícios" (BARTHES, 1973/1999, p.15). Dizer Madame Bovary c'est moi é produzir um ato cujos efeitos são visíveis na retroação característica dos atos contingentes, mas nem por isso atingindo menos a estrutura discursiva de toda uma época. O estilo de Flaubert funda "a escritura artesanal" (BARTHES, 1953/1972, p.51), na qual os incidentes da vida burguesa, até então tidos como exóticos e pitorescos, adquirem estatuto de arte. Ao assumir a estrutura da linguagem como pathos, Flaubert trabalha a frase e não a palavra, tornando aquela seu motivo de vida. Pode-se dizer que Flaubert passou sua vida a 'fazer frases'. Fazer tem aí um sentido bem preciso de construir, fabricar; portanto não é exagero dizer, com Barthes, que Flaubert inventa um novo objeto: a frase. "A frase de Flaubert é uma coisa" (Idem, p.138, grifo do autor).

Quando a poética de Arthur Rimbaud se apresenta, as dissonâncias são explicitadas com interrupções, cortes, laços semânticos sem qualquer linearidade. A incomunicabilidade com o leitor continua a ser ativamente trabalhada. "Eu é um outro”, frase espetacular de Rimbaud, tem a mesma estrutura da figura Flaubert/Bovary, ainda que seja legítimo observar que se trata de uma sintaxe 
outra. Seu fazer poético é um trabalho que destrói sentidos. O eu de Rimbaud é memória e, como tal, ficcional no limite máximo. A realidade em Rimbaud, diz Friedrich, é a realidade violenta e atroz da língua. Seu poema "Les Illuminations" (1986) reivindica um corte entre autor e leitor, demonstrando o resultado de uma operação impossível, que é aquela realizada pela obra de arte: "Eu anotava o inexprimível, agarrava o turbilhão”. É curioso observar que se trata da mesma posição de Barthes, quando ele propõe como tarefa da arte "inexprimir o exprimível” (BARTHES, 1999, p.22). A fronteira entre a literatura escrita e a literatura vivida encontra-se borrada. Rimbaud, como sabemos, deixa de escrever aos 19 anos, e parte para viver a ficção.

Chega-se enfim a Stéphane Mallarmé, cujo projeto literário aperfeiçoa a concepção baudelairiana de que a produção artística consiste não em reproduzir idealmente a realidade, mas construí-la, inventá-la. Sua poesia quer ser o nãolugar, no sentido de Augé (1994, p.73) também indicado por Foucault (1966 e 1995), no qual silêncio e linguagem podem se encontrar. Por isso, Friedrich pergunta se sua poesia ainda seria lírica. Mallarmé torna objetos em enigmas e obtém o sentido de estranhamento que Freud destacou como característica das coisas mais familiares. Despreza a biografia, preza o enigma. Dissociando Vida e Literatura, Mallarmé radicaliza o projeto que vinha sendo construído desde Rousseau, em que se dispensa o diálogo com o outro. Pondo em prática esta operação, destrói o triângulo autor-obra-leitor. Seu Eu/Outro é a linguagem. Precisamente por este motivo, o silêncio é acionado e trabalhado com grande ênfase. O poema ideal, diz ele, seria “o poema calado, em branco”, o que faz ressoar ainda mais a proposição lacaniana do que seria o cerne da psicanálise: um discurso sem palavras (LACAN, 1968-69/2004). Há em Barthes (1999) uma proposição análoga, na qual o escritor não tem de arrancar um verbo para calar o silêncio, mas o inverso.

O impacto da obra de Mallarmé pode ser visto em todos os aspectos no poema 'Un coup de dés'. Na apresentação do seu poema mais famoso, o poeta diz que desejaria que não lessem aquela Nota ou que, se folheada, fosse logo esquecida. Ele apela à "penetração do Leitor hábil" para aceitar a novidade do espaçamento, do silêncio, dos brancos de palavras, da dispersão. O exercício é evitar a narrativa, fazer uso da aparição/desaparição de palavras, acelerar/lentificar o movimento, dar lugar à Página. A aposta não incide sobre o entendimento, mas sobre a possibilidade de "abrir os olhos" (MALLARMÉ, 1976).

Ao inventar um leitor, bem diferente do leitor usual, Mallarmé pretende convocá-lo a um ato sempre inconcluso, aberto, cuja função não é a de decifrar, mas esbarrar no enigma. Talvez nenhum outro poeta tenha levado tão longe o trabalho de escrever a falta. "Eu digo: uma flor!, e, para além do esquecimento no qual minha voz não encontra qualquer contorno, enquanto algo diferente 
dos cálices conhecidos, musicalmente se levanta, ideia mesma e suave, a ausente de todos os buquês”. O que o poeta quer diante de si não é a flor, a flor que falta, mas a falta da flor, vazio radical. Entre a ausência real da coisa e a presença simbólica de um objeto, entre a reminiscência (imaginária) e a falta (real), entre lembrança e esquecimento, entre ideia e música, Mallarmé dirige-se ao enigma, trabalho em pura perda, sem meta, sem fim. Esta frase enigmática materializa, em sua literalidade, uma aproximação ao impossível real apresentado — inexprimido - pela obra de arte. Diante da linguagem, Mallarmé nos transmite um dizer para além ou aquém de qualquer enchimento imaginário. A escritura torna-se ato de invenção.

Para Blanchot (1949), o Livro ao qual Mallarmé se refere e se dirige é o símbolo da autonomia, da consciência sem sujeito e, ao mesmo tempo, encarnada, porque reduzida à forma material das palavras, isto é, sua sonoridade. O que compreender desta outra frase de Mallarmé: "Abolido bibelô de inanição sonora", a não ser sua própria literalidade, em que o vazio (inane) é presentificado e o adorno (bibelô) é abolido? Campos \& Pignatari (1974, p.28) veem neste escrito que o poeta Mallarmé, "libertando-se progressivamente dos ornatos discursivos, caminha para a extrema elipse e concisão". A pontuação é quase abolida, as palavras soltam-se no espaço da página. Falar não tem relação biunívoca com a eventualidade das palavras, a contingência do significante; a escritura literária pode levar ao limite a disjunção que funda o significante, fazendo dele outro que não si mesmo.

Blanchot indica o que nos impressiona ainda hoje em Mallarmé: a pura violência de sua paixão pela solidão do poeta, o silêncio contido na palavra. "É em vão que ele pede ao branco da página em branco, à margem ainda intacta, uma representação material do silêncio" (1949, p.43). O que está em jogo na operação poética, e Mallarmé leva este jogo ao limite, é a reversão da palavra em coisa, é a recuperação ou apresentação de uma impossibilidade: corresponder ao material.

Para Barthes, a revolução literária ocorrida na metade do século XIX está associada ao nascimento do capitalismo moderno e à consequente quebra das ilusões do liberalismo burguês. Da escritura clássica, em sua quase imutabilidade da linguagem como um bem comum, advém a pluralidade das escrituras modernas nas quais o universal escapa. Para ele, o romântico Victor Hugo já prefigurava a véspera da explosão da Palavra, o futuro da poesia moderna, com suas distorções do alexandrino, por exemplo. "A poesia moderna, efetivamente, posto que é preciso opô-la à poesia clássica e a toda a prosa, destrói a natureza espontaneamente funcional da linguagem" (BARTHES, 1953/1972, p.38). 


\section{FREUD ROMÂNTICO?}

Na extensa bibliografia que trata das relações entre a obra freudiana e artes, estilos de época, notadamente o romantismo, temos no Brasil um excelente livro, fruto de uma pesquisa acadêmica, chamado $O$ carvalho e o pinheiro: Freud e o estilo romântico, de Inês Loureiro (2002). A autora refaz no livro, de maneira muito generosa, uma investigação que convida o leitor a passar pelas inúmeras redes de sentido que ela foi construindo ao longo de anos de pesquisa sobre a relação de Freud com o romantismo. Ao tornar evidente tal percurso, possibilitando-nos testemunhar os meandros, as interrogações, idas e vindas do seu trajeto, Loureiro inscreve-se, competente e delicadamente, na tradição que ela própria aponta e que aproxima Freud de um grande comentador da sua obra, o canadense Patrick Mahony. O texto de Loureiro coaduna de modo exemplar com as características por ela apontadas a respeito do estilo de Freud e de Mahony: em resumo, trata-se de um discurso genético, aquele que apresenta, e não dissimula, os caminhos de elaboração, com seus atalhos, curvas, declives, retornos, paradas. Além disso, toma o leitor como companhia na viagem e dialoga com ele, por meio de artifícios retóricos muito bem costurados na escrita, propiciando a este leitor a experiência de coautorar uma obra.

A hipótese sustentada até o final do livro apresenta Freud como um pensador híbrido: ao mesmo tempo romântico e homem das luzes — problema insolúvel (Idem, p.24). No entanto, para esta autora, não há identidade entre psicanálise e romantismo (Idem, p.27). Para justificar esta afirmação, Loureiro recupera uma metáfora freudiana que, em carta endereçada a Lou Salomé, refere-se ao romantismo como sendo uma "madeira bem diferente" daquela que constitui a psicanálise (Idem, p.29), visto que o sistema de pensamento freudiano não é compatível com a nostalgia de uma plenitude perdida, nem tampouco com um projeto de "reencantamento do mundo" (Idem, p.27). Assim, fica claro que não há transcendência no pensamento freudiano. Tributária do romantismo alemão, a obra de Freud operará um desvio, uma inflexão, a este sistema. Mais uma vez, Loureiro nos apresenta o paradoxo da obra freudiana: ao mesmo tempo "representante do Iluminismo sombrio e do Racionalismo negro" (Idem, Idem).

Embora a autora vacile entre os termos ego e eu (Idem, p.41 e passim), indica de modo apropriado que para Freud o eu "é de uma precariedade absoluta”. Assim, este objeto eu, que vem sendo construído pela cultura ocidental desde Descartes com primazia ontológica, é desconstruído pela obra freudiana, afastando Freud radicalmente tanto dos pensadores idealistas quanto dos românticos.

Logo a seguir, temos mais uma observação bem formulada por Loureiro e, segundo ela, proveniente do ensaio de Jankélévitch: “a crítica da cultura em Freud não é exercida nem em nome de um ideal de passado, nem de um projeto 
futuro" (p.43), o que distinguiria enormemente Freud tanto dos românticos quanto dos iluministas.

Todo o exercício de formulação de Loureiro é construído para resultar no consistente argumento acerca do paradoxal sistema de pensamento freudiano, quando intimamente imbricados um Freud pessoalmente romântico e um Freud também iluminista, fundando uma obra que escapa ao romantismo tanto quanto ao iluminismo. Todavia, limitada por um recorte cuja gênese encontra-se no romantismo, poder-se-ia acrescentar a esta análise uma hipótese, cuja localização remeteria a um período bastante anterior, e que implicaria o século XVII na produção do objeto eu como matéria de investigação do referencial racional moderno.

Desde o momento em que, afetado pelo discurso histérico, Freud inicia sua pesquisa pelos caminhos do psiquismo humano, a literatura é referência constante. Seu biógrafo Max Schur lembra que, à beira da morte, Freud lia Balzac e, através dele, interrogava o saber literário. Uma hipótese a ser considerada supõe que Freud vê no texto literário, em primeiro lugar, a confirmação de sua invenção mais cara - o inconsciente. Assim, ele dialoga constantemente com Sófocles, Goethe, Shakespeare, Hoffmann, Ibsen, Zweig, Rilke, Thomas Mann, Balzac, Jansen, Dostoiévski, Milton, Flaubert, Schiller, Cervantes, Mark Twain, Anatole France, Heine, Hesse, Romain Rolland, Schnitzler, Thackeray (ASSOUN, 1996). Obtém, deste diálogo, ecos sonoros às formações do inconsciente que ele vai destacando em sua formalização: o sonho, o chiste, o ato falho, o sintoma.

Talvez por ser tão influenciado pelas artes da palavra, que têm no teatro grego uma constante fonte material, Freud introduz no seu vocabulário termos como 'romance', 'teatro', 'palco', 'cenário', 'cena'. Especificamente, emprega 'cena' incontáveis vezes, mais precisamente desde 1897, quando escreve a Fliess a respeito da "arquitetura da histeria”. Nessa carta, afirma que a fantasia, cuja origem é “acidental” (FREUD apud MASSON, 1986, p.240), tem relação direta com a verdade do sujeito. As fantasias são, segundo Freud, "ficções protetoras” (Idem) e seriam produzidas tendo como ponto de partida a cena originária [Urszene].

O cogito cartesiano inaugura uma cisão do sujeito humano com consequências que não deixam de renovar-se na invenção do humano. O cogito, súmula do idealismo, pode ser traduzido, a partir de Freud, por Penso (sujeito da enunciação), logo existo (eu, sujeito do enunciado). Há, nesta leitura, um eu derivado do pensamento, dividido pelo ato de pensar. A determinação de pensar num sujeito implica produção objetal, eu sou aquele que pensa, mas secundário e determinado pelo pensar. ${ }^{1}$ De que natureza seria este pensar? Freud, marcado por tal formulação cartesiana, leva-a ao pé da letra, respondendo que pensar é um ato inconsciente. Deste modo, retira o foco da consciência, produzindo

\footnotetext{
1 "Se é verdade que o Eu (Je) penso é uma determinação, ele implica a esse título uma existência indeterminada (Eu sou)” (DELEUZE, 1986).
} 
uma ruptura que, de resto, estava instalada no âmago do próprio sistema de pensamento cartesiano.

\section{DE RIMBAUD A FREUD: EU É UM OUTRO}

Para que Rimbaud pudesse proferir a fórmula célebre je est un autre, todo um movimento havia sido realizado no sentido de constituir, como vimos antes, um novo objeto: o eu. Queremos propor que, embora tal trabalho de invenção do eu tenha sido um dos marcos do romantismo, sobretudo o alemão, Freud, herdeiro deste movimento político, filosófico, estético, toma-o, de fato, como um dos pilares de sustentação de sua teorização, sem entretanto deixar-se levar pelas ressonâncias românticas deste eu objeto.

Num movimento dialético de presença e ausência, de neurônios permeáveis e impermeáveis, o Projeto de uma psicologia se desdobra no par desejo e desilusão. Como processo imaginário, a desilusão ocorre por um gap, um lapso na vivência de satisfação existente: é que entre percepção e alucinação impõe-se já a presença do eu como tradutor, mediador. O papel desempenhado pelo eu como "manto" (termo de Freud) de representações implica considerar a distinção entre percepção e representação (a alucinação é uma tentativa de representação) como decorrente de critérios estabelecidos, precária e localmente, pelo eu.

Retomando o percurso freudiano, vê-se que a alucinação é uma contingência retroativamente necessária na constituição do psiquismo. O mecanismo de reconstrução frente à angústia é correlato à experiência alucinatória descrita pela psicopatologia. Diante de uma realidade de desamparo ou de carência significante, surge a realização alucinatória, um mecanismo equivalente à realização de desejos do processo onírico. Este desdobramento da teoria onírica tem sua gênese no Projeto, seguindo para $A$ interpretação dos sonhos e outros textos posteriores. Freud o explicita mais tarde como "realização alucinatória de desejos" (FREUD, 1915/1973, p.2.086) e o termo, não sem razão, encontra-se no plural, pois se trata do Wunch [voto] e não de Begierde [desejo].

Comparando o mecanismo dos sonhos com processos patológicos, Freud diz que a fantasia de desejo se apresenta à percepção: “Dizemos então que o desejo onírico é alucinado, e sua realização encontra, como toda alucinação, completo crédito".

Ao eu - uma organização do sistema $\psi$, quer dizer, um sistema de representações — Freud atribui a inibição, uma inibição bastante precisa que consiste em evitar a alucinação, em ambas as direções: tanto a alucinação da vivência de satisfação quanto a da dor. Nestas vivências, adverte Freud, "tem de faltar a satisfação porque o objeto não tem existência real, mas só existe em representação de fantasia” (FREUD, 1895/1995, p.39). É aí justamente que surge a noção de signo, já anunciada com a "notícia”, um traço de memória. 
Na parte reservada à psicopatologia, o Projeto oferece uma compreensão que toca no aspecto contingente do psiquismo: o eu, regulado para não permitir o desprazer, através da atenção, é tomado de surpresa por uma recordação que "libera inesperadamente desprazer, e o eu toma conhecimento disso demasiadamente tarde; permitiu um processo primário porque não o esperava” (Idem, p.70-1). Toda uma formulação sobre a prematuridade do ser humano acha-se formulada aí. Uma referência a Aristóteles aparece nesse contexto: a proton pseudo histérica, pois Freud propõe que se interprete o sintoma histérico como decorrente de uma disposição precoce para a excitabilidade sexual em sujeitos histéricos. Concorrem na estruturação histérica dois componentes: um contingente, que seria um acontecimento ligado ao corpo (a masturbação, por exemplo); e outro, necessário, a precocidade da excitabilidade.

O mundo feito de linguagem, sobre o qual se debruça a psicanálise, intima Freud a operar sobre a experiência única, singular, excêntrica de cada sujeito, ensinando que a realidade de cada um é constituída, construída, de modo retroativo, por esta mesma experiência de discurso. O que significa dizer que cada ser humano, ao contar sua história, nada mais faz do que produzi-la. Por isso, Freud insiste que cada um de nós escreve o próprio romance familiar.

Tomemos, como exemplo, a complexa topologia que ele elabora para dar conta do aparelho psíquico, ao longo de sua vasta obra. Uma primeira tópica refere-se aos termos 'inconsciente', 'pré-consciente' e 'consciente', como consequência lógica dos princípios de prazer e de realidade. No entanto, não há neste desenho topológico qualquer traçado que nos induza a uma geografia cerebral. Não se trata de um modelo destinado a representar e localizar estruturas cerebrais, mas uma descrição de modos estruturais de funcionamento psíquico. Não se pode esquecer que ele ignora por completo noções caras à neurologia do seu tempo como 'hierarquia', 'mapeamento', 'instrumentalidade'. Apenas a título de ilustração, lembremos a tradução de 'inconsciente' que prepondera na literatura psicanalítica norte-americana: 'subconsciente'. Quando Freud introduz o termo 'Inconsciente’, jamais lhe dá a significação de instância localizada abaixo de algum órgão. E não por outro motivo, senão por trabalhar com a estrutura de linguagem, que toma corpo num ser de linguagem. Diferentemente de qualquer entendimento psicológico, Freud afirma com todas as letras que a psicanálise não atribui à consciência nenhuma função central ou essencialista; pelo contrário, trata-se de estado transitório, instância de qualidade — portanto fluida, maleável — que pode, inclusive, “faltar em absoluto” (FREUD, 1923/1973, p.2701). A dualidade cartesiana mente-corpo ou a tentativa de encontrar um lugar preciso no cérebro não o seduzem.

Tendo observado na clínica um ponto de impasse com a compulsão à repetição, Freud estabelece uma segunda tópica: isso, eu, e supereu (ideal do eu). Mais 
uma vez, a tradução Standard introduz elementos estranhos à letra de Freud: ele nunca fez uso dos termos latinos id, ego e superego. Freud escreveu em alemão e insistia em manter seus conceitos ao alcance da linguagem coloquial, atento às palavras que, compondo uma narrativa, constituem o sujeito da enunciação. Nesse sistema, as duas tópicas não se superpõem, tampouco há qualquer nível de graus ou hierarquia. O eu transita entre o consciente, o pré-consciente e o inconsciente, e Freud não se esquiva em sustentar o paradoxo de propor um sujeito que não é senhor nem mesmo em sua própria casa. Uma primeira descrição do eu nos é dada como uma progressiva diferenciação do isso, reino do princípio do prazer, da indiferenciação, lugar psíquico ao qual o real virá trazer suas marcas e levar o pequeno animal humano, já submetido à linguagem, a buscar satisfações substitutas num mundo doravante destituído de completude ou totalidade, vale dizer um mundo simbólico. O eu vai sendo constituído como um tampão para o excesso de energia que invade o aparelho e, ao fazê-lo, provoca conflitos; essa máquina desejante já é capaz de reconhecer exigências do agora mundo externo, e de resistir.

Uma das mais curiosas e impressionantes afirmações de Freud sobre o eu diz respeito à relação eu-corpo. Em “O eu e o isso” (1923/1973), o eu aparece como projeção de uma superfície, a do corpo. Deste modo, a construção de um corpo próprio acompanha passo a passo a constituição do eu. Não há possibilidade de separar os processos, o eu é uma estrutura de superfície corporal. Antes disso, as ilusórias e necessárias sensações de unidade e diferenciação eu-outro nada mais são do que promessas, escritas sob a forma de um nome dito próprio - mas de fato ainda impróprio, imposto — que será, ou não, apropriado na medida que o pequeno sujeito deixa pouco a pouco de se ver como 'o bebê', 'ele/ela' e passa a dizer-se 'eu'. É nesse período que a imagem especular organiza-se em corpo, com o auxílio do olhar do outro, acompanhada da experiência de ver-se como imagem projetada pelo espelho plano, experiência tanto física quanto psíquica que não devolve o real do corpo, mas sua imagem invertida, regular e sempre amparada pela troca de olhares, isto é, pela alteridade.

Em conformidade a uma lógica não cronológica de constituição do eu, posto que esse processo consome toda a vida do ser de linguagem, a formulação freudiana impede qualquer tentativa de psicologização. Deste modo, noções como personalidade, identidade, verdade são ignoradas por Freud em suas teorizações. Por acompanhar o desenrolar conflitivo e contraditório das vicissitudes humanas por meio de narrativas dos romances familiares, Freud introduz termos bem peculiares e, sobretudo, alheios ao mundo das ciências do seu tempo: identificações que se materializam e se desfazem ao longo da vida e não se fixam na infância; aspirações eróticas que o sujeito vive como necessidades; configurações instáveis em que o ficcional ganha estatuto de verdade, produzindo saber e transformações. 
Em seu papel de mediação entre o mundo e o isso, o eu assume uma posição de "estadista que sacrifica seus princípios ao desejo de conquistar a opinião pública” (Idem, p.2.726), com características de falsidade e oportunismo, diz Freud, mas de modo algum rebaixadas. Ao mesmo tempo, ele concebe o eu como a residência da angústia, o afeto que não engana. Como em toda a obra, Freud aproxima categorias aparentemente díspares, conflitantes entre si, num movimento lógico - e não psicológico — coerente com a principal característica do Inconsciente: não conhecer a contradição. Além disso, os parâmetros de Freud podem ser morais, sem por isso resvalarem para o moralismo.

Ao formular o pensamento como inconsciente, pensado não por alguém, mas pela própria estrutura que é a de linguagem, Freud se destaca da lógica cartesiana, segundo a qual há o grande Outro, como o lugar da garantia de sua existência de sujeito e da Verdade. A disjunção entre o pensar da consciência que diz 'eu sou' e o pensar inconsciente, o 'isso pensa', ultrapassa a filosofia cartesiana e permite a construção de outro racionalismo ao se constituir como campo do conhecimento.

Estes apontamentos na obra freudiana parecem indicar que o eu trazido à cena por Freud é uma instância que muito pouco deve à concepção romântica. Personagem fragmentário, sem qualquer sinal de grandeza, antes uma projeção da superfície corporal, como ele próprio indica, o eu carece por completo das conotações de inteireza, completude e idealização românticas, o que levou Emilio Rodrigué, um dos biógrafos contemporâneos mais reconhecidos de Freud, a lembrar que, em carta a Jung, Freud escrevera: "Na realidade, o ego é um verdadeiro palhaço que está sempre metendo o nariz onde não é chamado, para provar aos espectadores que tudo o que acontece no circo é sua obra" (FREUD apud RODRIGUÉ, 1995, p.5).

\section{MARCAS DO IMPRESSIONISMO EM FREUD}

Nesta altura do argumento, retomo a hipótese de que, para além de um referencial romântico ou iluminista, um outro racionalismo pode ser apontado na obra de Freud. Buscamos demonstrar que o percurso freudiano apresenta muitas características do impressionismo. Entretanto, quero deixar claro que etiquetar o estilo de uma época, ainda que em linhas gerais, não nos autoriza a identificar um campo com outro, nem tampouco obras de autores acadêmicos e artistas.

De acordo com Schapiro (2002), o termo ‘impressionismo’ referia-se a princípio ao trabalho de uns poucos pintores franceses do fim do século XIX, sendo depois estendido à literatura, à música "e até mesmo a um certo ponto de vista na ciência” (Idem, p.21). É importante destacar que o procedimento adotado por Freud para construir sua "nova psicologia”, e que hoje podemos chamar de práxis, corresponde ao que alguns estudiosos apontam ao identificar 
o modo peculiar de constituição deste estilo de época. Martelli (apud SCHAPIRO, 2002) indica que "a teoria impressionista sucedeu, e não precedeu, às observações dos pintores, que seus quadros nasceram dos processos inconscientes do olhar do artista” (p.21). Autores que se dedicam ao estudo do impressionismo destacam não apenas a revolução do pensamento decorrente deste movimento, uma virada na história da arte moderna (SALZSTEIN, 2002), mas, sobretudo, uma grande mudança no olhar humano, ou como diz Sagner "uma captação diferente do espaço e do tempo [...] que incluía o movimento do movimento" (2006, p.96).

Numa conferência sobre as "Vias de formação do sintoma” (FREUD, 19167/1973), Freud aborda um peculiar caminho de retorno da fantasia à realidade para caracterizar "o caminho da arte". Peculiar também é o modo como formaliza tal ideia em sua escritura, de resto uma característica presente em toda a sua obra. Ele não nos oferece uma definição direta, clara e homogênea do objeto pesquisado; ao invés, efetua um percurso descritivo e argumentativo para esboçar o tema, um modo de escritura característico do impressionismo literário. Os temas, não os objetos, são o foco e, mesmo assim, em nuances. O texto precisa dar a sensação, e Freud o realiza de modo magistral, de constante movimento. A solidez e a precisão do traço não interessam. O que conta é o momento irreproduzível, embora repetível na diferença dos tons e das pinceladas, da fluidez e da não-compactação dos elementos. Um após outro, os textos de Freud mostram o que Barthes nomeou de 'responsabilidade da forma', evidenciando-se em seu tom dialogal, não dogmático, que acolhe a incerteza, a própria ignorância, argumentos contrários ao seu, ao lado de um estilo literário já sublinhado por Roudinesco: "A morte, a sexualidade, a neurose, o monólogo interior, o desvelamento da alma, o suicídio formavam em Schnitzler a trama de um impressionismo literário, ao qual Freud foi tão sensível que expressou numa carta de 1922 o receio que lhe inspirava o encontro com o seu duplo" (ROUDINESCO \& PLON, 1998, p.690).

Não é difícil compreender os célebres passeios ao ar livre que Freud realizava até mesmo com pacientes, ao iniciar sua clínica. O modo utilizado pelos jovens pintores impressionistas de pintar ao ar livre, abandonando seus ateliês, visava fazer frente ao academicismo. Também o método foi assemelhado: aproximar-se da vida real, cotidiana, não para detê-la em imagens congeladas, mas para reter sua ação, o ato. Tela borrada por razões sobredeterminadas, sobrepostas, numa perspectiva contrária ao caráter de "janela” ou enquadramento renascentista. O que podemos extrair daí é a preeminência de um termo que o movimento romântico instaura e perdura com grandes consequências até a metade do século XX: a experiência como fonte legitimada da produção artística, científica, mundana. Começa-se a explorar um termo do qual a física se valerá para a constituição da 
Teoria da Relatividade. Trata-se da valorização da complementaridade, conceito que inclui aspectos contraditórios, porém congruentes na descrição de uma mesma realidade.

Freud preza o que a ciência do seu tempo despreza: o detalhe insignificante, sonhos, chistes, lapsos, equívocos, enigmas, o nonsense, o grotesco, o cômico, as brincadeiras infantis. A tarefa de identificar, por títulos, temas centrais como Édipo e Memória, por exemplo, é decepcionante. A palavra 'Édipo' se encontra em um único título de Freud que, não por acaso, se chama "A dissolução do complexo de Édipo”. O termo “Memória', confundido com seu projeto de fundar uma nova ciência, aparece explicitado como título em "Um transtorno de memória na Acrópole”. Neste título, como em tantos outros, as referências se dão com o emprego do indefinido: um transtorno de memória, uma lembrança infantil de Goethe, uma lembrança infantil de Leonardo da Vinci. Tanto no Projeto de uma psicologia quanto em $A$ interpretação dos sonhos, o termo 'memória' aparece em subitens, referindo-se a aspectos pontuais. Não encontraremos um texto sequer com a esperada "teoria” do Édipo ou da Memória. Também Lacan utiliza esta construção lógico-gramatical, quando diz que o inconsciente é estruturado como uma linguagem. É que a psicanálise não supõe que haja universo de discurso; portanto, só faz sentido dizer uma linguagem, não-toda.

Do mesmo modo, para expressar a complexidade e a sobredeterminação de atributos ou determinantes de um objeto ou acontecimento, os impressionistas praticavam a forma borrada, turvando as bordas, um modo de apresentação ao mesmo tempo matéria e sensação.

“Diferenças na palidez e rubor, nos sinais de saúde ou desconforto, por exemplo, não são entendidas [no impressionismo] como propriedades constantes de um objeto, mas como mutações mínimas causadas por experiências passageiras, o que requer um discernimento atento às gradações sutis das sensações." (SCHAPIRO, 2002, p.60)

Apesar de apostar na materialidade da superfície, os impressionistas operavam a quebra de fronteiras e o contraste familiaridade/estranheza, em função do lugar ocupado pelo observador: mais longe/mais perto. Desnecessário lembrar o quanto Freud trabalhou a mesma temática do estranho no familiar. A experiência impressionista é assombrosamente concreta ao demonstrar que a posição do corpo do observador interfere no processo de constituição do objeto:

“Os primeiros observadores dos quadros impressionistas, acostumados com uma representação mais lisa e detalhada, não podiam entendê-los de muito perto; não viam nada a não ser um padrão pouco familiar de pinceladas coloridas. Recuando 
alguns metros, ficavam encantados com o efeito. Algo novo tinha acontecido." (SCHAPIRO, 2002, p.66)

Além disso, uma das mais contundentes descrições do eu em Freud mostra a primazia da superfície: “O eu é, antes de tudo, um ser corpóreo, e não somente um ser superficial, mas sobretudo a projeção de uma superfície”. Em nota acrescentada em 1927, Freud sublinha: "O eu deriva em último termo das sensações corporais, principalmente daquelas produzidas na superfície do corpo" (1973/1923, p.2709). Superfície é um termo, sabemos, explorado por Freud em vários momentos de sua obra: O estranho (1919); Mais além do princípio do prazer (1920); Uma nota sobre o bloco mágico (1925); Inibição, sintoma e angústia (1926), dentre tantos outros. É, sobretudo, um termo próprio da pintura; não é à toa que Freud faz uso dele ao escrever o ensaio sobre Leonardo da Vinci (1910).

A etimologia da palavra 'superfície' remete ao que é acrescentado ao corpo, está sobre o corpo e que se faz visível (REY, 1993, p.2054). Lembremos também que são os pintores impressionistas aqueles que de fato investem revolucionariamente na apresentação da realidade visual da tela, trabalho impactante sobre a superfície, a textura. Permanecer na superfície parece ter sido paradoxalmente um dos pontos de maior relevância e o ponto sobre o qual mais críticas recaíram ao estilo impressionista. Também o trabalho com a cor não interpretada de antemão, isto é, a cor como coisa e não como conteúdo de significações implica uma recusa, poderíamos dizer, tanto da metafísica quanto da psicologia, indicando novas descrições subjetivas e, projeto explicitamente impressionista, impactando as ciências.

Assim, podemos concluir este artigo propondo uma nova e futura investigação: a associação entre Freud e os impressionistas, tomando como pano de fundo as ideias de fugacidade e luz, fragmentos em constante movimento, o complementar contraditório, as dicotomias instáveis, a importância do acidental, a tela do mundo como teia, rede de eventos, cujo significado não está fornecido, mas se constrói. Itens de uma modernidade que continuam a nos descrever e interrogar.

Recebido em 22/7/2007. Aprovado em 23/6/2008. 


\section{REFERÊNCIĀS}

AUGÉ, M. (1994) Não-lugares: introdução a uma antropologia da supermodernidade. Campinas: Papirus.

ASSOUN, P.-L. (1996) Littérature et psychanalyse. Paris: Ellipses.

BAUDELAIRE, C. (1855) Méthode de critique de l'idée moderne du progrès appliquée aux beaux-arts. Déplacement de la vitalité. Le Pays, 26 mai 1855. Disponível em: http://baudelaire.litteratura.com/ exposition_universelle.php?rub=oeuvre\&srub=cri\&id=259. Acesso em: 3/9/2007.

BARTHES, R. (1953/1972) Le degré zero de l'écriture. Suivi de Nouveaux Essais Critiques. Paris: Seuil.

. (1973/1999) O prazer do texto. São Paulo: Perspectiva. (1999) Crítica e verdade. São Paulo: Perspectiva.

BLANCHOT, M. (1949) La part du feu. Paris: Gallimard.

CAMPOS, A. de, PIGNATARI, D., CAMPOS, H. (1974) Mallarmé. São Paulo: Edusp.

DELEUZE. G. (1986) Sur quatre formules poetiques qui pourraient résumer la philosophie kantienne. In: Philosophie. Paris: Minuit. Disponível em: <http://br.geocities.com/rogelsamuel/DELEuze. html> (Trad. Andréa Estevão). Acesso em: 3/6/2007.

FOUCAULT, M. (1966) Les mots et les choses: une archéologie des sciences humaines. Paris: Gallimard. (1995) Microfísica do poder. Rio de Janeiro: Graal.

FREUD, S. (1915/1973) Los instintos y sus destinos. In: Obras completas de Sigmund Freud. Trad. Luis Lopez-Ballesteros y de Torres. Madrid: Biblioteca Nueva. (Tomo II)

(1916-7) “Leccion XXIII, Vías de formación de síntomas. Lecciones introductorias al psicoanálisis”, (Tomo II).

(1923) “El yo y el ello” (Tomo III).

. (1895/1995) Projeto de uma psicologia. Trad., notas Osmyr Faria Gabbi Jr. Rio de Janeiro: Imago.

FRIEDRICH, H. (1978) Estrutura da lírica moderna: da metade do século XIX a meados do século XX. São Paulo: Duas Cidades.

GABBI JR., O. F. (1995) Notas críticas sobre o Projeto, in FREUD, Sigmund (1895). Projeto de uma psicologia. Rio de Janeiro: Imago.

LACAN, J. (1968-69/2004) Seminario XVI. De un Otro al otro. (Inédito)

LOUREIRO, I. (2002) O carvalho e o pinheiro: Freud e o estilo romântico. São Paulo: Escuta/Fapesp.

MALLARMÉ, S. (1976) Igitur, Divagations, Un coup de dés. Paris: Gallimard.

MASSON, J. M. (Ed.) (1986) A correspondência completa de Sigmund Freud para Wilhelm Fliess: 1887-1904. Rio de Janeiro: Imago.

REY, A. (1993) Dictionnaire historique de la langue française. Montréal: Dicorobert.

RODRIGUÉ, E. (1995) O século da psicanálise: 1895-1995. São Paulo: Escuta.

RORTY, R. (1993) Contingence, ironie \& solidarité. Traduit par Pierre-Emmanuel Dauzart. Paris: Armand Colin. 
ROUDINESCO, E. \& PLON, M. (1998) Dicionário de Psicanálise. Trad. Vera Ribeiro e Lucy Magalhães. Rio de Janeiro: Jorge Zahar.

SAGNER, K. (2006) Claude Monet: uma festa para os olhos. Trad. Casa das Línguas. Köln: Taschen.

SALZSTEIN, S. (2002). Meyer Schapiro: a realidade concreta do trabalho de arte (prefácio), in SCHAPIRO, M. (2002) Impressionismo: reflexões e percepções. Trad. Ana Luiza Dantas Borges. São Paulo: Cosac \& Naify.

SCHAPIRO, M. (2002) Impressionismo: reflexões e percepções. Trad. Ana Luiza Dantas Borges. São Paulo: Cosac \& Naify.

TODOROV, T. (2003) Poética da prosa. Trad. Claudia Berliner. São Paulo: Martins Fontes.

Denise Coutinho

denisecoutinho1@gmail.com 